\title{
Variations in biomass, production and respiration of fine roots in a young larch forest
}

\author{
Rui CuI $^{a}$, Takashi Hirano ${ }^{b, \dagger}$, Lifei Sun ${ }^{b, c}$, Munemasa Teramoto ${ }^{c, d}$ and Naishen Liang ${ }^{c}$ \\ $\left(\begin{array}{c}{ }^{\mathrm{a}} \text { Graduate School of Agriculture, Hokkaido University, Sapporo 060-8589, Japan } \\ { }^{\mathrm{b}} \text { Research Faculty of Agriculture, Hokkaido University, Sapporo 060-8589, Japan } \\ { }^{\mathrm{c}} \text { Center for Global Environmental Research, National Institute for Environmental Studies, Tsukuba 305-8506, Japan } \\ { }^{\mathrm{d}} \text { Present address: Arid Land Research Center, Tottori University, Tottori 680-0001, Japan }\end{array}\right)$
}

\begin{abstract}
Root respiration $\left(R_{\mathrm{r}}\right)$ plays a crucial role in the global carbon balance, because $R_{\mathrm{r}}$ accounts for about a half of soil respiration in typical forest ecosystems. Plant roots are different in metabolism and functions according to size. Fine roots, which are typically defined as roots $<2 \mathrm{~mm}$ in diameter, perform important ecosystem functions and consequently govern belowground carbon cycles mainly because of their high turnover rates. However, the phenological variation of fine root functions is not well understood yet. To quantitatively examine the fine root functions, we adopted an approach to partition $R_{\mathrm{r}}$ into growth respiration $\left(R_{\mathrm{g}}\right)$ and maintenance respiration $\left(R_{\mathrm{m}}\right)$ using a modified traditional model, in which $R_{\mathrm{g}}$ was proportional to root production, and $R_{\mathrm{m}}$ was proportional to root biomass and exponentially related to soil temperature. We conducted a field experiment on soil respiration and fine root biomass and production over a year in a larch-dominated young forest developing on the bare ground after removing surface organic soil to parameterize the model. The model was significantly parameterized using the field data measured in such simplified field conditions, because we could control spatial variation in heterotrophic respiration and contamination from roots other than fine roots. The annual $R_{\mathrm{r}}$ of all roots was $94 \mathrm{~g} \mathrm{C} \mathrm{m}^{-2} \mathrm{yr}^{-1}$ and accounted for $25 \%$ of total soil respiration on average. The annual $R_{\mathrm{r}}$ was partitioned into fine root $R_{\mathrm{g}}$, fine root $R_{\mathrm{m}}$ and coarse root $R_{\mathrm{m}}$ by 30,44 and $26 \%$, respectively; coarse root $R_{\mathrm{g}}$ was presumed to be negligible. Fine root $R_{\mathrm{g}}$ and $R_{\mathrm{m}}$ varied according to the seasonal variations of fine root production and soil temperature, respectively; the contribution of fine root biomass was minor because of its small seasonality. The contribution of $R_{\mathrm{g}}$ to total fine root respiration was lower in the cold season with low production.
\end{abstract}

Key words: Fine root, Growth respiration, Maintenance respiration, Root respiration, Soil respiration

\section{Introduction}

Net ecosystem production (NEP) is the tiny balance of two huge $\mathrm{CO}_{2}$ fluxes of gross primary production (GPP) and ecosystem respiration (RE). Soil respiration $\left(R_{\mathrm{s}}\right)$ accounts for $30-80 \%$ of RE on an annual basis in forest ecosystems (Davidson et al., 2006) but typically $70 \%$ in temperate forests (Ryan and Law, 2005). On a global scale, $R_{\mathrm{s}}\left(98 \mathrm{Pg} \mathrm{C} \mathrm{yr}^{-1}\right.$; Bond-Lamberty and Thomson, 2010) accounts for about $80 \%$ of GPP (123 Pg C $\mathrm{yr}^{-1}$; Beer et al., 2010). These facts indicate that $R_{\mathrm{s}}$ plays a crucial role in terrestrial carbon cycles.

The $R_{\mathrm{s}}$ is composed of autotrophic respiration $\left(R_{\mathrm{a}}\right)$ and heterotrophic respiration $\left(R_{\mathrm{h}}\right)$. The $R_{\mathrm{a}}$ is equivalent to respiration from roots (root respiration: $R_{\mathrm{r}}$ ) using photosynthate and non-structural carbohydrates as substrate (NSC), whereas $R_{\mathrm{h}}$ is the microbial decomposition of soil organic matter (SOM) and carbohydrates derived from roots (Moyano et al., 2009). The $R_{\mathrm{a}}$

Received; December 22, 2020

Accepted; March 4, 2021

†Corresponding author: hirano@env.agr.hokudai.ac.jp

DOI: 10.2480/agrmet.D-20-00049 and $R_{\mathrm{h}}$ respond to temperature and moisture in a different manner (Scott-Denton et al., 2005; Boone et al., 1998). Thus, to examine the environmental response of $R_{\mathrm{s}}, R_{\mathrm{s}}$ has been partitioned into $R_{\mathrm{r}}$ and $R_{\mathrm{h}}$ by root-exclusion methods, such as trenching (Sha et al., 2021). In forest ecosystems, the ratio of $R_{\mathrm{r}}$ to $R_{\mathrm{s}}\left(R_{\mathrm{r}} / R_{\mathrm{s}}\right)$ ranged between 10 and $90 \%$ depending on vegetation types and seasons (Hanson et al., 2000) but typically 45-50\% (Subke et al., 2006).

Roots are classified into non-woody fine roots and woody coarse roots by anatomical traits and physiological functions. Fine roots are physiologically active apexes of root branches and conventionally defined as thinner roots $<2 \mathrm{~mm}$ in diameter (e.g. Brunner et al., 2013; Finér et al., 2011). Fine roots absorb and transport water and nutrients, whereas coarse roots, which are $\geq 2 \mathrm{~mm}$ in diameter, transport them and anchor and support their aboveground part. The net primary production (NPP) of fine roots is large and consequently accounted for $22 \%$ of global terrestrial NPP (McCormack et al., 2015). In boreal forests, although fine root biomass accounted for only $16 \%$ of root biomass, $73 \%$ of all belowground NPP arose from fine root NPP (Yuan and Chen, 2010); fine root NPP can be an index of belowground NPP (Yuan and Chen, 2013). Because root turnover rates become faster as root diameter becomes thinner (Yuan and Chen, 2010), fine roots supply a large amount of litter to the soil together with labile exudate, which stimulate soil microbial activities and change soil carbon stock. Majority of soil carbon 
in forest ecosystems certainly results from fine root turnover (Richter et al., 1999). The respiration rate normalized by dry matter was much higher from fine roots than from coarse roots (Makita et al. 2012; Rewald et al., 2014). When the respiration rate was scaled up based on biomass data, stand-level respiration of fine roots accounted for $50-70 \%$ of $R_{\mathrm{s}}$ in plantations of acacia and eucalyptus (Chen et al., 2009; Marsden et al., 2008). Thus, fine roots are the most important component contributing to belowground carbon dynamics in forest ecosystems (Finér et al., 2011). However, the function of fine roots in carbon cycles is not well understood yet (McCormack et al., 2015), because the production and turnover of fine roots substantially depend on plant functional types and climates (Lambers et al., 2008; Yuan and Chen, 2012). In addition, information is still lacking on belowground phenology (Abramoff and Finzi, 2015).

Fine root respiration has been frequently partitioned into growth $\left(R_{\mathrm{g}}\right)$ and maintenance $\left(R_{\mathrm{m}}\right)$ components (Amthor, 2000; McCree, 1974; Thornley, 1970; Penning de Vries, 1974), plus occasionally into ion uptake $\left(R_{\mathrm{i}}\right)$ (Chapin et al., 2011; Johnson, 1990; Lambers et al., 2008) to examine belowground phenology and predict root respiration using a simple model, in which $R_{\mathrm{g}}$, $R_{\mathrm{m}}$ and $R_{\mathrm{i}}$ are proportioned to growth (production), biomass and nutrient uptake of fine roots, respectively. Terrestrial biosphere models, such as Biome-BGC, are adopting the partitioning model (Sun Q et al., 2017). Although there is a criticism that the scientific basis is lacking in the quantitative division between $R_{\mathrm{g}}$ and $R_{\mathrm{m}}$ (Cannell and Thornley, 2000; Sweetlove et al., 2013), experimental data indicate that the model is a valuable tool in understanding the carbon balance of plants and the ecological controls on plant respiration (Lambers et al., 2008; Chapin et al., 2011). The model has been parameterized and verified mostly based on laboratory experiment data taken in the controlled environment (e.g. Lambers et al., 2008; M'Bou et al., 2010). Only two studies from field experiments reported the partitioning of fine root respiration using the model (George et al., 2003; Sun et al., 2020). George et al. (2003) estimated annual values of $R_{\mathrm{g}}, R_{\mathrm{m}}$ and $R_{\mathrm{i}}$ (due to nitrogen uptake) from a short-term chamber experiment and literature information. Sun et al. (2020) (our previous study) conducted a field experiment for more than a year in adjacent two mature forests: an evergreen spruce plantation and a larch-dominated deciduous forest. We quantified annual $R_{\mathrm{g}}$ and $R_{\mathrm{m}}$ and discussed their difference between the two forests. However, the results can have large uncertainty arising from field conditions, such as a high ratio of coarse roots, rich understory species in the deciduous forest and a high spatial variation in litter accumulation, root density and SOM especially in the deciduous forest, because the forests were mature at the age over 35 years and the deciduous forest was damaged by windthrow. These site conditions probably increased the spatial variation of $R_{\mathrm{h}}$ and the contamination from other roots than fine roots, which resulted in uncertainty in $R_{\mathrm{r}}$ separation from $R_{\mathrm{s}}$ and model parameterization. Although it is a challenge to substantially decrease uncertainty in field experiments, the following site conditions can improve data reliability: 1) homogeneity in tree age, 2) young forest with less litter accumulation and coarse roots, 3) no or little understory species, and 4) a small amount of SOM.
We measured soil $\mathrm{CO}_{2}$ efflux and fine root dynamics from 2017 to 2018 in a young larch forest regenerating on the topsoil-removed bare ground to meet the above conditions. Using carefully measured field data, the objectives of this study are 1) to continuously separate fine root $R_{\mathrm{r}}$ from total $R_{\mathrm{s}}, 2$ ) to robustly parameterize the partitioning model, 3) to partition the $R_{\mathrm{r}}$ into $R_{\mathrm{g}}$ and $R_{\mathrm{m}}$ using the model, and 4) to show the phenological variations of fine root respiration along with fine root production and biomass.

\section{Material and Methods}

\subsection{Study site}

A field experiment was conducted in a regenerating young forest dominated by Japanese larch (Larix kaempferi) with sparse Japanese white birth (Betula platyphylla) in Tomakomai national forest, southern Hokkaido, Japan $\left(42^{\circ} 44.27^{\prime} \mathrm{N}, 141^{\circ} 31.42^{\prime} \mathrm{E}\right.$, $116 \mathrm{~m}$ above sea level by Google Earth). The study site was used to be a larch plantation established on volcanogenous regosol with a high water permeability but was severely destroyed by a windstorm due to a typhoon in 2004 (Sano et al., 2010); all stems of both fallen and standing trees were removed, and then organic surface soil (A horizon) was scraped out together with stumps, coarse woody debris, litter accumulation, regenerating understory species and buried seeds in 2006. Because the B horizon is lacking, unweathered pumice stones (C horizon) have been exposed. Wind-blown seeds of larch and birch first germinated on the $\mathrm{C}$ horizon in a horizontal flat place in 2007 and have been growing despite poor nutrients. The site was located between two forests used for field experiments by Sun et al. (2020). The ground surface was sparsely covered with stunted ground vegetation dominated by red raspberry (Rubus idaeus). Aboveground biomass (AGB) of trees taller than $2 \mathrm{~m}$ was 16.7 and $20.9 \mathrm{t} \mathrm{ha}^{-1}$, respectively, in 2017 and 2018, of which larch trees accounted for $65-67 \%$. Tree density, tree height and diameter at $1.3 \mathrm{~m}$ height in 2018 were 3380 trees $\mathrm{ha}^{-1}, 4.27 \pm 1.21 \mathrm{~m}$ and $3.9 \pm 2.2 \mathrm{~cm}$ (mean \pm 1 standard deviation (SD)), respectively. In 2016, bulk density, total carbon (C) concentration, total nitrogen $(\mathrm{N})$ concentration and $\mathrm{C} / \mathrm{N}$ ratio were $0.446 \pm 0.042 \mathrm{~g} \mathrm{~cm}^{-3}, 15.2 \pm 13.8 \mathrm{~g} \mathrm{~kg}^{-1}, 0.742 \pm 0.794$ $\mathrm{g} \mathrm{kg}^{-1}$ and $24.5 \pm 5.8$ (mean $\pm 1 \mathrm{SD}$ ), respectively, for top 15 -cm-thick fine soil $(<2 \mathrm{~mm})$. The $\mathrm{C}$ concentration showed a decreasing tendency with a distance from tree stems according to the amount of leaf litter fall; the $\mathrm{C}$ concentration accounted for about $30 \%$ of that of a nearby mature larch-dominated forest studied by Sun et al. (2020).

Decadal mean annual air temperature and precipitation were $8.1 \pm 0.3^{\circ} \mathrm{C}$ and $1346 \pm 159 \mathrm{~mm} \mathrm{yr}^{-1}$, respectively, from 2010 to 2019 at a meteorological station (Tomakomai) $14 \mathrm{~km}$ apart from the study site. The highest and lowest monthly mean air temperatures in the same decade were $21.0^{\circ} \mathrm{C}$ in August and $-3.9^{\circ} \mathrm{C}$ in January, respectively. Snow usually covers the ground for about four months between early December and early April.

\subsection{Experimental design}

Ten pairs of aluminum collars were installed in May 2017 around isolated larch trees. Six pairs of collars were set at $0.5 \mathrm{~m}$ (Near), and the others were set at $1.0 \mathrm{~m}$ (Far) from the target 
larch stems. The other trees were more than $1.5 \mathrm{~m}$ away from collars. In each pair, two collars were set at a $0.4 \mathrm{~m}$ space on the bare ground without ground vegetation. Collars were $0.5 \mathrm{~m} \times$ $0.5 \mathrm{~m}$ in size and inserted $3 \mathrm{~cm}$ deep into the soil. We trenched a collar (TC) of each pair in early July 2017 by inserting four PVC boards $20 \mathrm{~cm}$ deep into the soil around the collar to exclude root respiration. We found by eye from soil profiles that almost all roots appeared in the top $15 \mathrm{~cm}$ layer. The other collar (SC) was used for fine root sampling without trenching.

\subsection{Soil $\mathrm{CO}_{2}$ efflux}

A field experiment was conducted at intervals of about three weeks between May 2017 and August 2018 with a six-month suspension from mid-November 2017 to mid-May 2018 mainly because of snow. Soil $\mathrm{CO}_{2}$ efflux was manually measured on each collar with the same method as in Sun et al. (2017; 2020). Young plants germinating in collars were carefully pulled out before measurement, though it was rare. The measurement was conducted between 10:00 and 16:00 on each date with a portable closed-chamber system equipped with two 0.5-m-tall cubic chambers, an air pump, a datalogger (CR1000; Campbell Scientific Inc., Logan, UT, USA), a $\mathrm{CO}_{2}$ analyzer (LI820; Li-Cor Inc., Lincoln, NB, USA), thermometers (MHP; Omega Engineering, Stanford, CA, USA) and a soil moisture sensor (SM150; Delta-T Device Ltd., Cambridge, UK). The datalogger was used to control the system and record data. $\mathrm{CO}_{2}$ concentration in the chamber was measured every $5 \mathrm{~s}$ during chamber closing for $3 \mathrm{~min}$. The $\mathrm{CO}_{2}$ increasing rate was determined from the continuous data by the least squares method, and then soil $\mathrm{CO}_{2}$ efflux was calculated from the increasing rate, chamber air temperature, air pressure and chamber height. Soil temperature $\left(T_{\mathrm{s}}\right)$ at a depth of $5 \mathrm{~cm}$ and volumetric soil water content (SWC) of the top 5 -cm soil were measured immediately after the efflux measurement in each collar. Also, $T_{\mathrm{s}}$ at a depth of $6 \mathrm{~cm}$ and $\mathrm{SWC}$ at a depth of $3 \mathrm{~cm}$ were monitored at four points at a nearby station $150 \mathrm{~m}$ from the study site (Hirano et al., 2017); we used the data measured at an open place where the $\mathrm{C}$ horizon was exposed like the study site.

After trenching in early July 2017, $\mathrm{CO}_{2}$ efflux from TC $\left(R_{\mathrm{TC}}\right)$ corresponded to the sum of original $R_{\mathrm{h}}$ and $\mathrm{CO}_{2}$ emissions through the decomposition of dead roots $\left(R_{\mathrm{DR}}\right)$ by trenching (Sha et al., 2021). The method to estimate $R_{\mathrm{DR}}$ is described later. Meanwhile, $\mathrm{CO}_{2}$ efflux from SC $\left(R_{\mathrm{SC}}\right)$ corresponded to total $R_{\mathrm{s}}$. Although $\mathrm{SC}$ was disturbed by soil sampling, its effect on $\mathrm{CO}_{2}$ efflux was insignificant because sampling area was negligible (Sun et al., 2020). Thus, the sum of fine and coarse root respirations $\left(R_{\mathrm{r}}\right)$ was determined for each pair of collars, as $R_{\mathrm{r}}=$ $R_{\mathrm{SC}}-\left(R_{\mathrm{TC}}-R_{\mathrm{DR}}\right)$. Since the distance from a target larch tree was the same, two collars in a pair were expected to have similar root density and litter fall.

We applied the following simple exponential model to analyze the effect of $T_{\mathrm{s}}\left({ }^{\circ} \mathrm{C}\right)$ on soil $\mathrm{CO}_{2}$ efflux $\left(R_{\mathrm{c}}, \mu \mathrm{mol} \mathrm{m}{ }^{-2} \mathrm{~s}^{-1}\right)$ on each collar.

$$
R_{\mathrm{c}}=a \cdot \exp \left(b \cdot T_{\mathrm{s}}\right)
$$

where $a$ and $b$ are fitting parameters. From the temperature response parameter $(b)$, we calculated $Q_{10}$, which is the factor by which $R_{\mathrm{c}}$ increases with a $10^{\circ} \mathrm{C}$ temperature rise. In addition, the effect of SWC was analyzed using the temperature-normalized $R_{\mathrm{c}}$ at a base temperature $\left(T_{\mathrm{b}}\right)$.

$$
R_{\mathrm{b}}=R_{\mathrm{c}} \cdot \exp \left(b \cdot\left(T_{\mathrm{b}}-T_{\mathrm{s}}\right)\right)
$$

In this study $T_{\mathrm{b}}$ was set at $15^{\circ} \mathrm{C}$, mean $T_{\mathrm{s}}$ for the snow-free season. Using the relationship of $R_{\mathrm{c}}$ with $T_{\mathrm{s}}$ and/or SWC, $R_{\mathrm{SC}}$ and $R_{\mathrm{TC}}$ were calculated half hourly on every collar from the monitoring data of $T_{\mathrm{s}}$ and/or SWC. Daily $R_{\mathrm{r}}$ was calculated for each pair from daily $R_{\mathrm{SC}}, R_{\mathrm{TC}}$ and $R_{\mathrm{DR}}$.

\subsection{Decomposition of dead roots}

We conducted a root litter bag experiment to determine the decay constant ( $k$ ) (Gholz et al., 2000; Silver and Miya, 2001; Sun et al. 2020). In June 2017, we collected topsoil to a depth of $15 \mathrm{~cm}$ from the total area of $1 \mathrm{~m}^{2}$ and extracted fine toots from mixed soil samples with the same method as described later. The root samples were air-dried and weighed, and then some were oven dried. We determined the water content of air-dried samples from the dry weight and calculated the dry weight of air-dried samples. Air-dried samples corresponding to $0.48 \mathrm{~g}$ of dry weight were put into each 2-mm mesh bag of $10 \mathrm{~cm} \times$ $10 \mathrm{~cm}$ in size. The sample amount was equivalent to measured root density. A total of 60 bags were buried at a depth of $10 \mathrm{~cm}$ at about $1 \mathrm{~m}$ from a larch stem in July 2017. Ten bags were collected six times until October 2018, and remaining samples were oven-dried and weighed. The $k$ was determined by fitting the following equation (Wieder and Lang, 1982) to the data.

$$
Y=Y_{0} \cdot \exp (-k \cdot t)
$$

where $Y$ is the dry weight of remaining root samples in bags $\left(\mathrm{g} \mathrm{bag}^{-1}\right)$ at elapsed time $t$ (days), $Y_{0}$ the initial dry weight of root samples $\left(0.48 \mathrm{~g} \mathrm{bag}^{-1}\right)$ and $k$ the decay constant $\left(\mathrm{d}^{-1}\right)$. As for the $k$ of coarse roots, we used a reported value of $0.44 \times 10^{-3} \mathrm{~d}^{-1}(=0.16$ $\mathrm{yr}^{-1}$ ) from a nearby larch-dominated forest (Sun et al., 2020).

The $R_{\mathrm{DR}}\left(\mathrm{g} \mathrm{C} \mathrm{m}^{-2} \mathrm{~d}^{-1}\right)$ at elapsed time $t$ (days) was calculated daily, separately for fine and coarse roots using the following equation.

$$
R_{\mathrm{DR}}=C_{\mathrm{c}} \cdot\left(X_{\mathrm{t}-1}-X_{\mathrm{t}}\right)=C_{\mathrm{c}} \cdot X_{0} \cdot \exp (-k \cdot t) \cdot\{\exp (k)-1\}
$$

where $C_{\mathrm{c}}$ is the carbon concentration of roots $\left(\mathrm{g} \mathrm{g}^{-1}\right), X_{\mathrm{t}}$ the dry weight of remaining dead roots $\left(\mathrm{g} \mathrm{m}^{-2}\right)$ at $t$ and $X_{0}$ the initial dry weight of dead roots $\left(\mathrm{g} \mathrm{m}^{-2}\right)$. For both fine and coarse roots, we used $C_{\mathrm{c}}$ of $0.484 \mathrm{~g} \mathrm{~g}^{-1}$ (Neumann et al., 2020), which was the average value of fine roots in European forests. The $X_{0}$ of fine roots were set at 66 (Near) and 29 (Far) $\mathrm{g} \mathrm{m}^{-2}$, which were based on fine root biomass measured by soil core sampling from SC in July 2017. As for coarse roots, $X_{0}$ were determined to be 55 (Near) and 49 (Far) $\mathrm{g} \mathrm{m}^{-2}$ from soil sampling down to $15 \mathrm{~cm}$ in May and September 2019.

\subsection{Biomass and production of fine roots}

The biomass and production of fine roots were measured by the same method as in Sun et al. (2020). Fine root biomass density $\left(B_{\mathrm{f}}, \mathrm{g} \mathrm{m}^{-2}\right)$ was measured by soil coring five times from July 2017 to August 2018 for about 14 months with a six-month suspension from mid-November 2017 to mid-May 2018. Soil 
cores were extracted down to $15 \mathrm{~cm}$ with a stainless-steel edged tube with an inner diameter of $2.4 \mathrm{~cm}$. We sampled three cores from each SC every time, using a perforated board for positioning. Sampling positions were randomly selected from a grid with $8 \mathrm{~cm}$ spacing and not reused. In total, the pit area by sampling amounted to $68 \mathrm{~cm}^{2}$ for each SC, which accounted for only $2.7 \%$ of each collar area. Soil samples were put into PVC tubes and stored in a freezer, and then dispersed in a vat filled with tap water. Only living fine roots with a diameter $<2 \mathrm{~mm}$ were visually extracted, dried at $70^{\circ} \mathrm{C}$ for 48 hours and weighed. The fine roots should have originated from larch trees, because the other plants did not exist in the vicinity.

Fine root production rates $\left(P_{\mathrm{f}}, \mathrm{g} \mathrm{m}^{-2}\right.$ period $\left.^{-1}\right)$ were measured by the ingrowth core method (e.g. Vogt et al., 1998) with plastic hair curlers wrapped in a $2 \mathrm{~mm}$ mesh sheet. The cores were $20 \mathrm{~cm}$ long and had a diameter of $2.3 \mathrm{~cm}$. Air-dried fine soil, which was collected from the study site and sieved through $2 \mathrm{~mm}$ meshes, was put into the cores up to $15 \mathrm{~cm}$. For each SC, three cores were inserted down to $15 \mathrm{~cm}$ into the pits made by soil core sampling, and three cores inserted previously were collected simultaneously with the core sampling. Collected ingrowth cores were put into PVC tubes and stored in a freezer, and then dry weight of fine roots was determined with the same method as described above. Fine roots penetrate root-free soil in ingrowth cores through meshes during a period between two sampling dates. Thus, the dry weight of fine roots in ingrowth cores corresponds to $P_{\mathrm{f}}$. Also, annual fine root mortality $\left(M_{\mathrm{f}}, \mathrm{g} \mathrm{m}^{-2} \mathrm{yr}^{-1}\right)$ was calculated as a difference between annual $P_{\mathrm{f}}$ and an annual difference in $B_{\mathrm{f}}\left(\Delta B_{\mathrm{f}}\right)$ $\left(M_{\mathrm{f}}=P_{\mathrm{f}}-\Delta B_{\mathrm{f}}\right)$. We converted dry weight to carbon using a factor of 0.484. In addition, turnover rates were calculated as the ratio of annual $P_{\mathrm{f}}$ and mean $B_{\mathrm{f}}$ (Brunner et al., 2013).

\subsection{Partitioning root respiration}

Originally, $R_{\mathrm{r}}$ was partitioned into $R_{\mathrm{g}}$ and $R_{\mathrm{m}}$ by the following equation (Amthor, 2000; Thornley, 1970).

$$
R_{\mathrm{r}}=R_{\mathrm{g}}+R_{\mathrm{m}}=g_{\mathrm{R}} \cdot P_{\mathrm{f}}+m_{\mathrm{R}} \cdot B_{\mathrm{f}}
$$

where $g_{\mathrm{R}}$ is the growth respiration coefficient and $m_{\mathrm{R}}$ the maintenance respiration coefficient. We modified the equation as follows, considering field conditions.

$$
\begin{aligned}
& \text { Model 1: } R_{\mathrm{r}}=R_{\mathrm{g}}+R_{\mathrm{m}}=c \cdot P_{\mathrm{f}}+d \cdot \exp \left(f \cdot T_{\mathrm{s}}\right) \cdot\left(B_{\mathrm{f}}+B_{\mathrm{c}}\right) \\
& \text { Model 2: } R_{\mathrm{r}}=R_{\mathrm{g}}+R_{\mathrm{m}}=c \cdot P_{\mathrm{f}}+\exp \left(f \cdot T_{\mathrm{s}}\right) \cdot\left(d_{\mathrm{f}} \cdot B_{\mathrm{f}}+d_{\mathrm{c}} \cdot B_{\mathrm{c}}\right)
\end{aligned}
$$

where $c$ corresponds to $g_{\mathrm{R}}\left(\mathrm{g} \mathrm{C} \mathrm{g}\right.$ dry matter $\left.(\mathrm{DM})^{-1}\right), d$ the $R_{\mathrm{m}}$ of unit biomass at $0^{\circ} \mathrm{C}\left(\mathrm{g} \mathrm{C} \mathrm{g} \mathrm{DM}^{-1} \mathrm{~d}^{-1}\right), f$ a temperature coefficient $\left({ }^{\circ} \mathrm{C}^{-1}\right), B_{\mathrm{c}}$ coarse root biomass $\left(\mathrm{g} \mathrm{m}^{-2}\right)$. In Model $2, d$ is separated into $d_{\mathrm{f}}$ for fine roots and $d_{\mathrm{c}}$ for coarse roots, considering the difference in respiration efficiency (Makita et al., 2012; Rewald et al., 2014). We added temperature effect on $R_{\mathrm{m}}$ in an exponential form, because temperature directly affects $R_{\mathrm{m}}$ (Moyano et al., 2009; Thornley, 2011). Although tree survey suggested that coarse roots had grown during the study period, we assumed that the contribution of coarse roots to $R_{\mathrm{g}}$ was negligible because of no available data. However, we incorporated $B_{\mathrm{c}}$ into the second term on the assumption that coarse roots showed the same temperature response as fine roots.
We determined the parameters of $c, d$ and $f$ by curve fitting to measured data of $R_{\mathrm{r}}, P_{\mathrm{f}}, T_{\mathrm{s}}, B_{\mathrm{f}}$ and $B_{\mathrm{c}}$. For the fitting, mean daily $R_{\mathrm{r}}\left(\mathrm{g} \mathrm{C} \mathrm{m}^{-2} \mathrm{~d}^{-1}\right)$ for each period of core sampling intervals was used. The $P_{\mathrm{f}}$ was converted to daily value $\left(\mathrm{g} \mathrm{m}^{-2} \mathrm{~d}^{-1}\right)$. The $B_{\mathrm{f}}\left(\mathrm{g} \mathrm{m}^{-2}\right)$ was a mean of two consecutive data measured at the beginning and the end of the period. The $T_{\mathrm{s}}\left({ }^{\circ} \mathrm{C}\right)$ was mean soil temperature for the period. The $B_{\mathrm{c}}$ was set at 55 and $49 \mathrm{~g} \mathrm{~m}^{-2}$, respectively, at Near and Far positions, neglecting its seasonal variation. All the data were prepared from each pair of collars $(n=10)$ for each period $(n=5)$. In comparison with our previous study (Sun et al., 2020), the data size for curve fitting increased considerably from five to 50 to obtain a robust result. In addition, we incorporated $B_{\mathrm{c}}$ in the second term, considering the temperature response of $R_{\mathrm{m}}$ of coarse roots and deleted a constant term $(h)$, which represented the respiration of coarse roots and herbaceous roots.

\subsection{Statistical analysis}

We applied Student's $t$-test to compare two means, assuming homoscedasticity. Also, we applied two-way repeated measures ANOVA to test the effects of factors. The significance of curve fitting and parameters were tested using $F$-test and $t$-test, respectively. Uncertainties ( $\pm 1 \mathrm{SD}$ ) of annual $R_{\mathrm{g}}$ and $R_{\mathrm{m}}$ were estimated from those of the parameters and measurements using the law of error propagation. All the statistical analyses were conducted with a software package (Origin Pro 2015 J; Origin Lab Corporation, Northampton, MA, USA).

\section{Results}

\subsection{Environmental conditions}

We conducted a field experiment on fine root dynamics from July 2017 to August 2018. During the annual period between August 2017 and July 2018, mean air temperature and total precipitation were $7.7^{\circ} \mathrm{C}$ and $1425 \mathrm{~mm}$ at the Tomakomai meteorological station. The annual mean air temperature was low beyond the range of its decadal mean $\pm 1 \mathrm{SD}\left(8.1 \pm 0.3^{\circ} \mathrm{C}\right)$ between 2010 and 2019, whereas annual precipitation was within the decadal range $\left(1346 \pm 159 \mathrm{~mm} \mathrm{yr}^{-1}\right)$. The $T_{\mathrm{s}}$ at a depth of $6 \mathrm{~cm}$ showed an obvious seasonal variation with the maximum of $27.4^{\circ} \mathrm{C}$ in mid-July 2017 and the minimum of $-0.64^{\circ} \mathrm{C}$ in early December 2017 on a daily basis (Fig. 1a). Under snow cover, $T_{\mathrm{s}}$ was stable at $-0.26 \pm 0.14^{\circ} \mathrm{C}$ between December and February. The SWC at $3 \mathrm{~cm}$ increased to $0.21 \mathrm{~m}^{3} \mathrm{~m}^{-3}$ in late November and rapidly decreased by soil freezing in December (Fig. 1b). In January and February, SWC was stable at $0.067 \pm 0.005 \mathrm{~m}^{3} \mathrm{~m}^{-3}$, and then gradually increased in March with the thaw of frozen soil.

Soil temperature measured simultaneously with flux measurement was not significantly different between positions nor between treatments (Table 1). Meanwhile, SWC was significantly lower at Far positions $(p<0.05)$.

\subsection{Soil $\mathrm{CO}_{2}$ efflux}

Soil $\mathrm{CO}_{2}$ efflux $\left(R_{\mathrm{c}}\right)$ was measured three and 15 times, respectively, before and after trenching in early July 2017 (Fig. 2). Overall, $R_{\mathrm{c}}$ varied according to a seasonal variation in $T_{\mathrm{s}}$ (Fig. 1a). Before trenching, no significant difference was found between $\mathrm{SC}$ and TC in all pairs $(p>0.05)$, which suggested 
a)

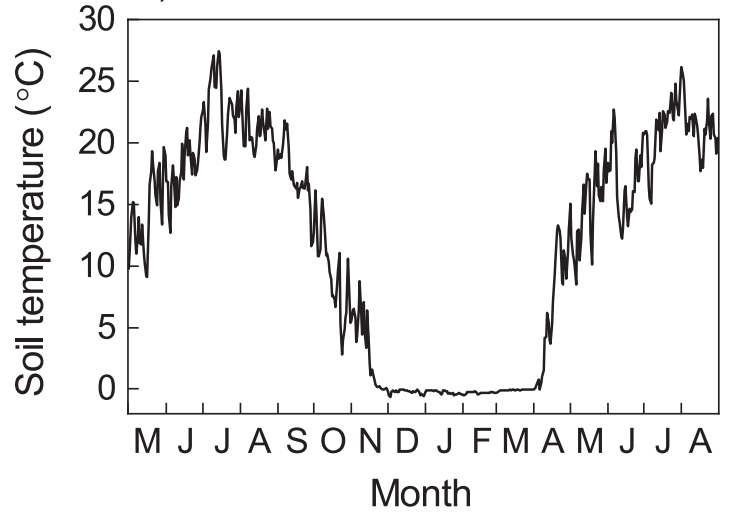

b)

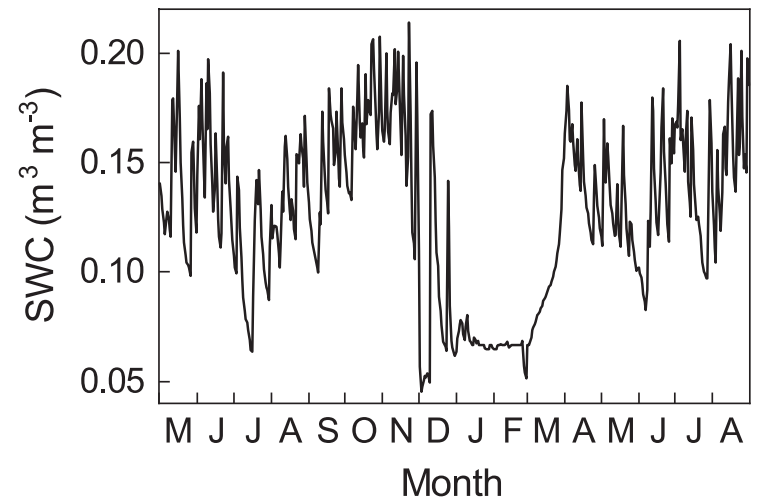

Fig. 1. Temporal variations in daily means of soil temperature $\left(T_{\mathrm{s}}\right)$ at a depth of $6 \mathrm{~cm} \mathrm{(a)}$ and volumetric soil water content (SWC) at a depth of $3 \mathrm{~cm}$ (b) measured at a nearby station $150 \mathrm{~m}$ from the study site from May 2017 to August 2018.

a) Near

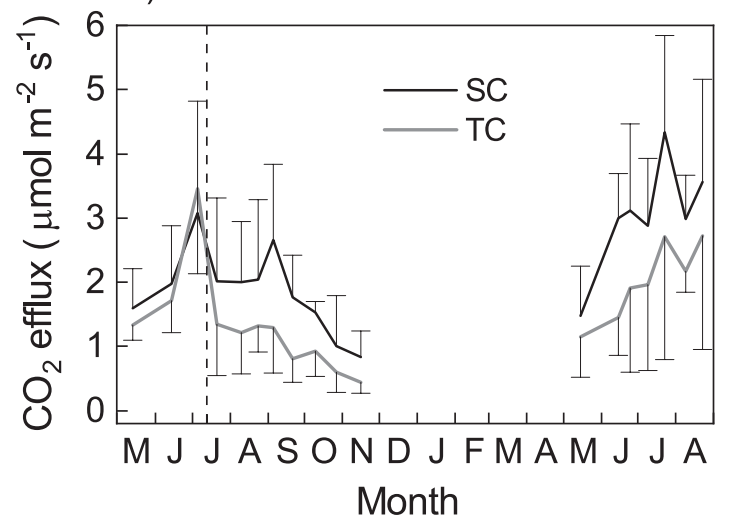

b) Far

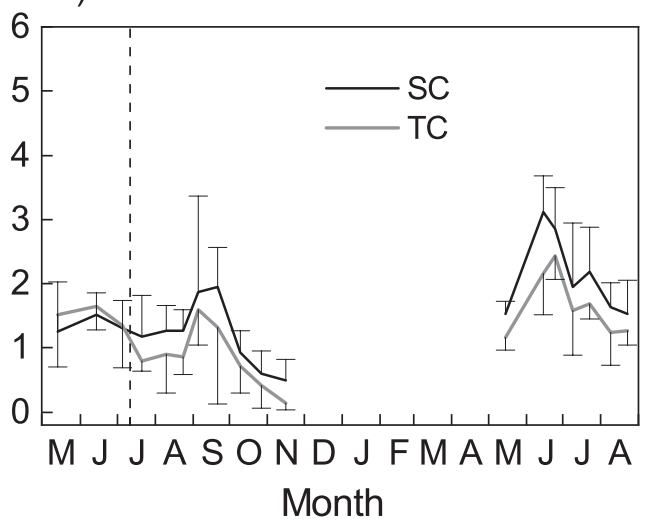

Fig. 2. Temporal variations in soil $\mathrm{CO}_{2}$ efflux $\left(R_{\mathrm{c}}\right)$ in collars for root sampling (SC) and trenched collars (TC) at Near $(n=6)$ (a) and Far $(n=4)$ (b) from May 2017 to August 2018. Vertical bars denote 1 standard deviation. The dashed vertical lines denote the time of trenching.

Table 1. Soil temperature $\left(T_{\mathrm{s}}\right)$ at a depth of $5 \mathrm{~cm}$ and volumetric soil water content (SWC) of the top 5-cm soil measured in each collar immediately after $\mathrm{CO}_{2}$ efflux measurement. Means $( \pm 1$ standard deviation) were shown in each cell. Two-way repeated measure ANOVA was applied.

\begin{tabular}{cccc}
\hline Position & Treatment & $T_{\mathrm{s}}\left({ }^{\circ} \mathrm{C}\right)$ & $\mathrm{SWC}\left(\mathrm{m}^{3} \mathrm{~m}^{-3}\right)$ \\
\hline Near & Control & $20.4 \pm 7.1$ & $0.097 \pm 0.024$ \\
& Trenched & $19.5 \pm 6.9$ & $0.088 \pm 0.018$ \\
Far & Control & $20.7 \pm 7.4$ & $0.079 \pm 0.022$ \\
& Trenched & $19.8 \pm 7.2$ & $0.080 \pm 0.016$ \\
\hline \multirow{3}{*}{ ANOVA $(p$-value $)$} & Position & 0.89 & 0.018 \\
& Treatment & 0.65 & 0.44 \\
& Interaction & 0.99 & 0.36 \\
\hline
\end{tabular}

that initial $R_{\mathrm{c}}$ was almost the same in each pair. Meanwhile, significant difference was found between the two collars in all pairs $(p<0.05)$ after trenching. Mean $R_{\mathrm{c}}$ after trenching was $2.41 \pm 1.50(\mathrm{SC})$ and $1.54 \pm 1.11(\mathrm{TC}) \mu \mathrm{mol} \mathrm{m} \mathrm{m}^{-2} \mathrm{~s}^{-1}$ at Near and $1.69 \pm 0.90(\mathrm{SC})$ and $1.30 \pm 0.70$ (TC) $\mu \mathrm{mol} \mathrm{m} \mathrm{m}^{-2} \mathrm{~s}^{-1}$ at Far. The $R_{\mathrm{c}}$ showed a significant positive exponential relationship with $T_{\mathrm{s}}$ (Eq. 1) on each collar $(p<0.05)$. Figure 3 resulted from mean $R_{\mathrm{c}}$ on each measuring date after trenching. The $Q_{10}$ values were $2.01(\mathrm{SC})$ and $2.39(\mathrm{TC})$ at Near and $1.58(\mathrm{SC})$ and 1.62 (TC) at Far for $T_{\mathrm{s}}$ at a depth of $5 \mathrm{~cm}$. In contrast, no significant linear nor curvilinear relationship was found between temperature-normalized $R_{\mathrm{c}}\left(R_{\mathrm{b}}\right.$, Eq. 2$)$ and SWC (data not shown). Thus, we estimate $R_{\mathrm{SC}}$ and $R_{\mathrm{TC}}$ half hourly for every pair of collars from $T_{\mathrm{s}}$ monitoring data using Eq. 1 .

The result of the root litter bag experiment is shown in Fig. 4. A negative exponential equation (Eq. 3) was fitted to the data in 2017 and 2018 separately, because no change was measured in the winter between mid-November and mid-May. The $k$ values before mid-November and after mid-May were $2.1 \times 10^{-3}\left(r^{2}=\right.$ $0.88)$ and $1.7 \times 10^{-3} \mathrm{~d}^{-1}\left(r^{2}=0.97\right)$, respectively. We set $k$ at 0 in the winter. If the equation is fitted to all data, $k$ is calculated to be $0.44 \times 10^{-3} \mathrm{~d}^{-1}\left(r^{2}=0.74\right)$, which is equivalent to $0.36 \mathrm{yr}^{-1}$.

Daily $R_{\mathrm{DR}}$ was calculated from the $k$ values using Eq. 4, and then daily $R_{\mathrm{s}}\left(R_{\mathrm{SC}}\right)$ was partitioned into $R_{\mathrm{h}}$ and $R_{\mathrm{r}}$ of all roots (Fig. 5). Since $R_{\mathrm{SC}}$ and $R_{\mathrm{TC}}$ were estimated from $T_{\mathrm{s}}$, all respiration components varied according to the seasonal variation of $T_{\mathrm{s}}$ (Fig. 1). Under snow, $R_{\mathrm{s}}, R_{\mathrm{h}}$ and $R_{\mathrm{r}}$ were stable at $0.61,0.37$ and $0.24 \mathrm{~g} \mathrm{C} \mathrm{m}^{-2} \mathrm{~d}^{-1}$, respectively, at Near and $0.42,0.33$ and 
a) Near

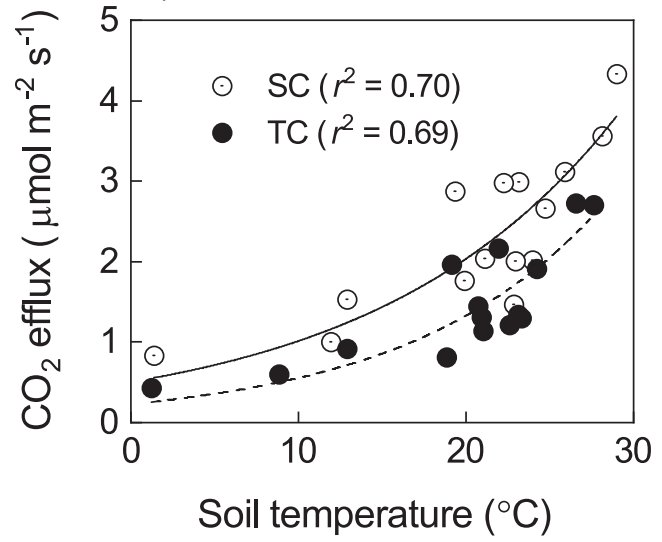

b) Far

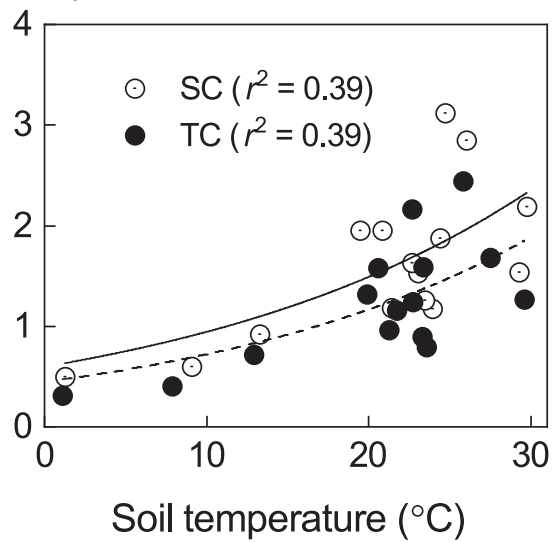

Fig. 3. Relationship of soil $\mathrm{CO}_{2}$ efflux $\left(R_{\mathrm{s}}\right)$ with soil temperature $\left(T_{\mathrm{s}}\right)$ in collars for root sampling $(\mathrm{SC})$ and trenched collars (TC) at Near $(n=6)$ (a) and Far $(n=4)$ (b) from May 2017 to August 2018. An exponential curve (Eq. 1) was significantly fitted; $r^{2}$ values were shown.

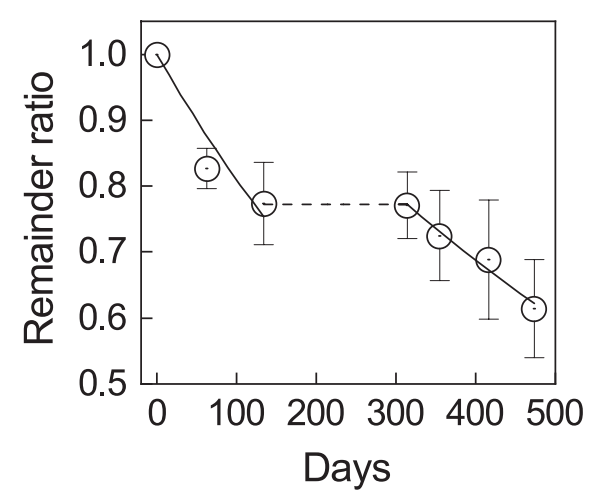

Fig. 4. Temporal variation in fine root litter left in root litter bags (remainder ratio) from July 2017 to October 2018. Means ( \pm 1 standard deviation) were plotted $(n=10)$. A negative exponential equation (Eq. 3) was separately fitted to data in 2017 and 2018. No change was found in fine root litter between mid-November 2017 and mid-May 2018 (dashed line).
$0.08 \mathrm{~g} \mathrm{C} \mathrm{m}^{-2} \mathrm{~d}^{-1}$, respectively, at Far, which indicates that the ratios of $R_{\mathrm{r}}$ to $R_{\mathrm{s}}$ were 0.39 and 0.19 , respectively, at Near and Far under snow. The $R_{\mathrm{m}}$ of coarse roots $\left(R_{\mathrm{m} \_ \text {coarse }}\right)$ was calculated using Eq. 6 . Thus, the difference between $R_{\mathrm{r}}$ and $R_{\mathrm{m} \text { _coarse }}$ correspond to $R_{\mathrm{r}}$ of fine roots, which were 0.20 and $0.04 \mathrm{~g} \mathrm{C} \mathrm{m}^{-2} \mathrm{~d}^{-1}$, respectively, at Near and Far under snow. Annual $\mathrm{CO}_{2}$ efflux was calculated between August 2017 and July 2018 (Table 2). All the $\mathrm{CO}_{2}$ effluxes were larger at Near than at Far, though only $R_{\mathrm{SC}}$ was significantly different $(p<0.05)$. The ratios (Far / Near) of $R_{\mathrm{SC}}$ $\left(R_{\mathrm{s}}\right), R_{\mathrm{h}}$ and $R_{\mathrm{r}}$ were $0.63,0.83$ and 0.28 , respectively. The $R_{\mathrm{DR}}$ accounted for $3 \%$ of $R_{\mathrm{s}}$ at both positions. The $R_{\mathrm{r}}$ accounted for 37 and $16 \%$ of $R_{\mathrm{s}}$, respectively, at Near and Far.

Similarly, measured $R_{\mathrm{CS}}$ was partitioned into $R_{\mathrm{h}}$ and $R_{\mathrm{r}}$ for each collar pair. The $R_{\mathrm{h}}$ and $R_{\mathrm{r}}$ significantly responded to $T_{\mathrm{s}}(p<0.05)$ according to Eq. 1 . The $Q_{10}$ values of $R_{\mathrm{h}}$ and $R_{\mathrm{r}}$ were $2.02 \pm 1.28$ and $2.01 \pm 1.21$ (mean $\pm 1 \mathrm{SD}$ ), respectively, at Near $(n=6)$ and $2.15 \pm 1.20$ and $2.14 \pm 1.29$, respectively, at $\operatorname{Far}(n=4)$. No significant difference was found between $R_{\mathrm{h}}$ and $R_{\mathrm{r}}$ at both positions.

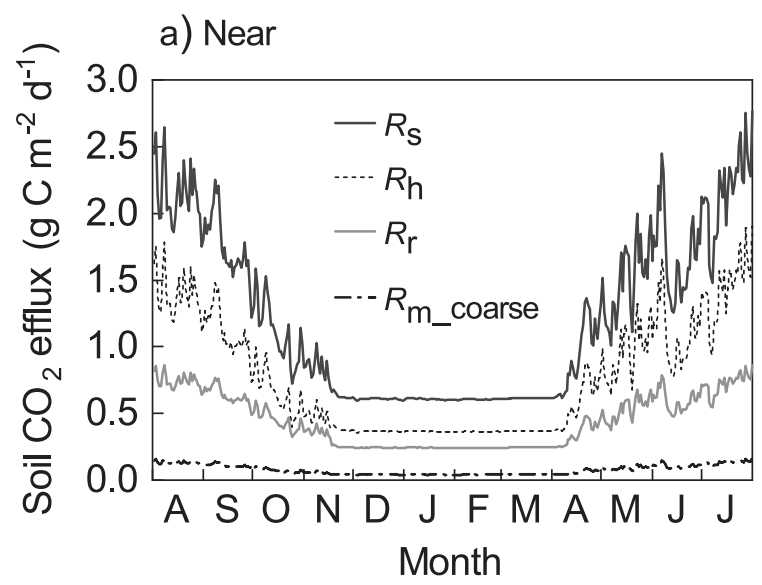

b) Far

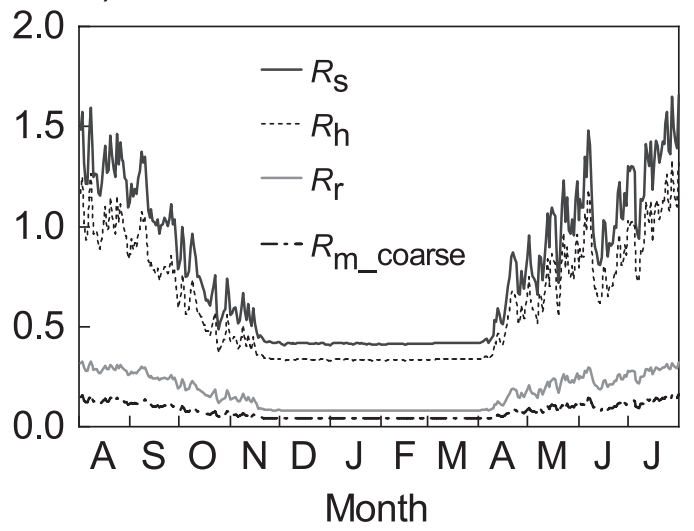

Fig. 5. Temporal variations in mean daily soil respiration $\left(R_{\mathrm{s}}\right)$, heterotrophic respiration $\left(R_{\mathrm{h}}\right)$, root respiration $\left(R_{\mathrm{r}}\right)$ and coarse root maintenance respiration $\left(R_{\mathrm{m} \_ \text {coarse }}\right)$ at Near $(n=6)(\mathrm{a})$ and $\operatorname{Far}(n=4)$ (b) calculated from the monitoring data of soil temperature $\left(T_{\mathrm{s}}\right)$ between August 2017 and July 2018. 


\subsection{Biomass and production of fine roots}

Fine root biomass $\left(B_{\mathrm{f}}\right)$ at Near showed a small peak in early September 2017, and then tended to increase from November until late August 2018 (Fig. 6a). Similarly, $B_{\mathrm{f}}$ at Far showed an increasing tendency in the warm season. In contrast, fine root production $\left(P_{\mathrm{f}}\right)$ showed a clear seasonal variation both at Near and Far (Fig. 6b); it decreased during the fall and increased during the late spring and summer. In the cold season between mid-November and mid-May, including the snowy season for about four months, $P_{\mathrm{f}}$ was small at $0.035 \pm 0.018$ and $0.043 \pm$ $0.041 \mathrm{~g} \mathrm{~m}^{-2} \mathrm{~d}^{-1}$, respectively, at Near and Far. The $P_{\mathrm{f}}$ showed a significant exponential relationship $(p<0.05)$ with $T_{\mathrm{s}}$ at a depth of $5 \mathrm{~cm}$ in the same form as Eq. 1 (Fig. 7a), which resulted in $Q_{10}$ values of 4.48 and 2.51, respectively, at Near and Far. The high $Q_{10}$ of 4.48 reflects a large seasonal variation in $P_{\mathrm{f}}$ at Near (Fig. 6b). Also, $B_{\mathrm{f}}$ showed a significant exponential relationship ( $p<0.05$ ), though $Q_{10}$ values were lower with 1.08 and 1.49, respectively, at Near and Far. A significant linear relationship with a slope of $1.20\left(r^{2}=0.43, p<0.001\right)$ was found between $R_{\mathrm{r}}$ and $P_{\mathrm{f}}$, regardless of positions (Fig. 8a). The relationship between $R_{\mathrm{r}}$ and $B_{\mathrm{f}}$ was also significant $\left(r^{2}=0.33, p<0.01\right)$ (Fig. 8b), whereas $P_{\mathrm{f}}$ was not significantly correlated with $B_{\mathrm{f}}$ $(p>0.10)$. Annually, $P_{\mathrm{f}}(p<0.05)$ and mean $B_{\mathrm{f}}(p<0.01)$ were significantly larger at Near than Far, whereas the turnover rate

Table 2. Annual soil respiration $\left(R_{\mathrm{SC}}\right.$ or $\left.R_{\mathrm{s}}\right)$, soil $\mathrm{CO}_{2}$ efflux in trenched collars $\left(R_{\mathrm{TC}}\right), \mathrm{CO}_{2}$ emissions through dead root decomposition in trenched collars $\left(R_{\mathrm{DR}}\right)$, heterotrophic respiration $\left(R_{\mathrm{h}}\right)$ and root respiration $\left(R_{\mathrm{r}}\right)\left(\mathrm{g} \mathrm{C} \mathrm{m}^{-2} \mathrm{yr}^{-1}\right)$ at Near $(n=6)$ and $\operatorname{Far}(n=4)$. Means $\left( \pm 1\right.$ standard deviation) were shown. Numbers in parentheses denote percentages against $R_{\mathrm{SC}}$.

\begin{tabular}{cccccc}
\hline Position & \multicolumn{1}{c}{$R_{\mathrm{SC}}\left(R_{\mathrm{s}}\right)$} & $R_{\mathrm{TC}}$ & $R_{\mathrm{DR}}$ & $R_{\mathrm{h}}$ & $R_{\mathrm{r}}$ \\
\hline Near & $493 \pm 111(100)$ & $326 \pm 75(66)$ & $13(3)$ & $313 \pm 75(63)$ & $181 \pm 123(37)$ \\
Far & $311 \pm 68(100)$ & $269 \pm 79(86)$ & $8(3)$ & $261 \pm 79(84)$ & $51 \pm 34(16)$ \\
\hline
\end{tabular}

a) Biomass

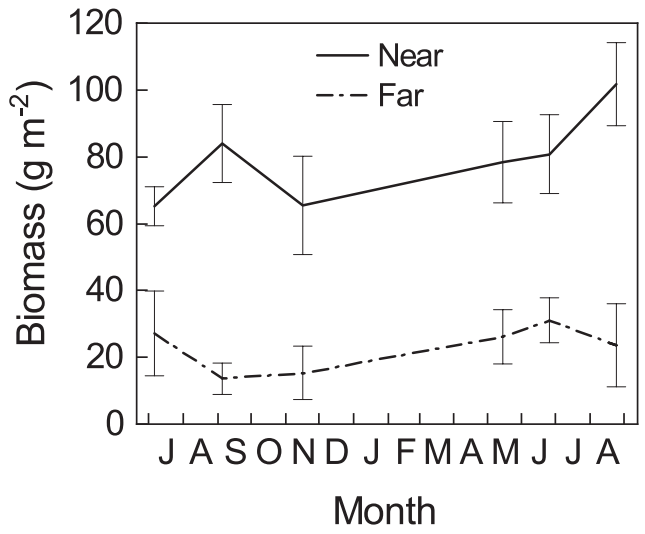

b) Production

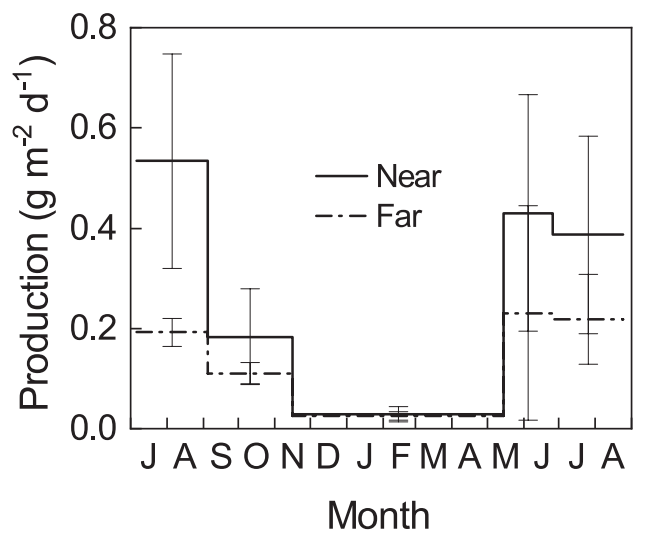

Fig. 6. Temporal variations in fine root biomass $\left(B_{\mathrm{f}}\right)(\mathrm{a})$ and fine root production $\left(P_{\mathrm{f}}\right)(\mathrm{b})$ at Near $(n=6)$ and Far $(n=4)$ from July 2017 to August 2018. Means ( \pm 1 standard deviation) were shown.

a) Production

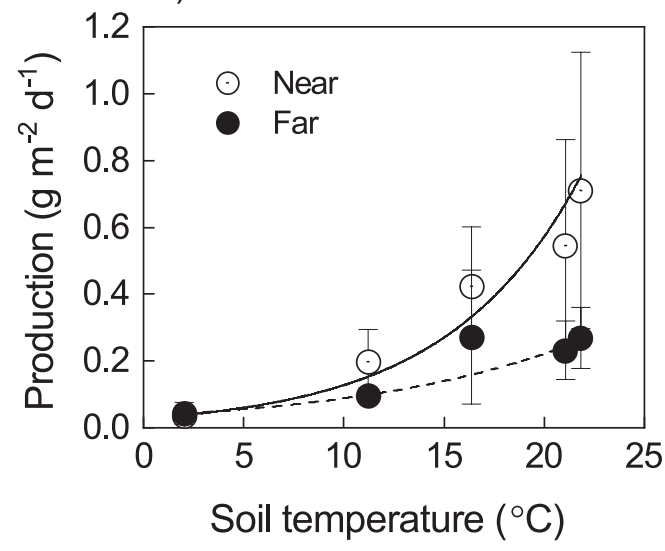

b) Biomass

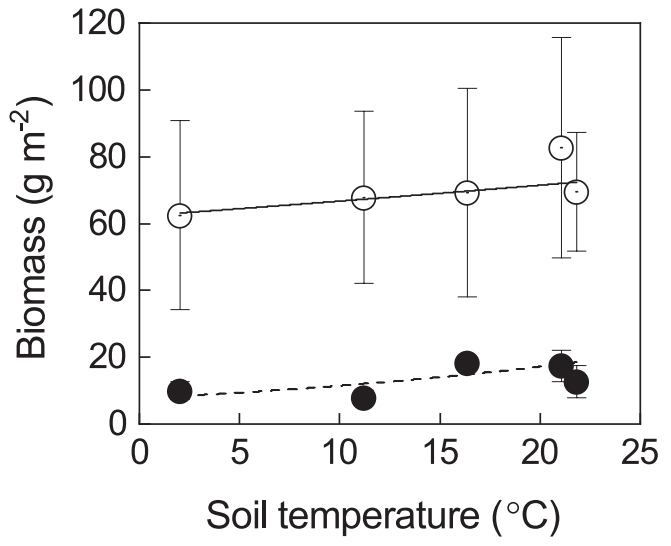

Fig. 7. Relationships of fine root production $\left(P_{\mathrm{f}}\right)$ with soil temperature $\left(T_{\mathrm{s}}\right)(\mathrm{a})$ and fine root biomass $\left(B_{\mathrm{f}}\right)$ with soil temperature $\left(T_{\mathrm{s}}\right)(\mathrm{b})$ at Near $(n=6)$ and Far $(n=4)$. Soil temperature was averaged for each interval of root sampling. Means ( \pm 1 standard deviation) were plotted. An exponential curve (Eq. 1) was significantly fitted. 
a) Production

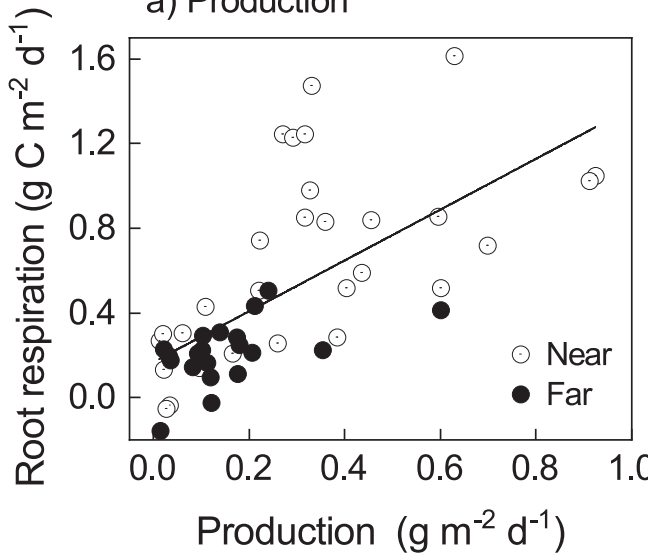

\section{b) Biomass}

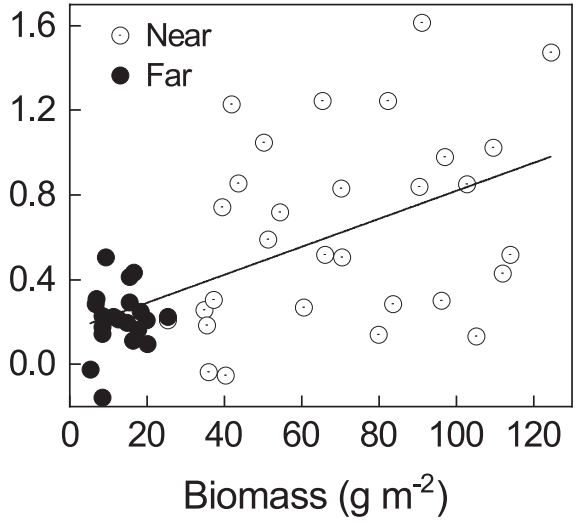

Fig. 8. Relationship of root respiration $\left(R_{\mathrm{r}}\right)$ with fine root production $\left(P_{\mathrm{f}}\right)(\mathrm{a})$ or fine root biomass $\left(B_{\mathrm{f}}\right)(\mathrm{b})$ at Near and Far. Root respiration was averaged for each interval of root sampling. A significant regression line was drawn for each scatter plot.

Table 3. Annual values of fine root production $\left(P_{\mathrm{f}}\right)$, annual increase in fine root biomass $\left(\Delta B_{\mathrm{f}}\right)$, fine root mortality $\left(M_{\mathrm{f}}\right)$, mean fine root biomass $\left(B_{\mathrm{f}}\right)$ and fine root turnover rates at Near $(n=6)$ and Far $(n=4)$. Means $( \pm 1$ standard deviation $)$ were shown.

\begin{tabular}{cccccc}
\hline Position & $\begin{array}{c}P_{\mathrm{f}} \\
\left(\mathrm{g} \mathrm{m}^{-2} \mathrm{y}^{-1}\right)\end{array}$ & $\begin{array}{c}\Delta B_{\mathrm{f}} \\
\left(\mathrm{g} \mathrm{m}^{-2} \mathrm{y}^{-1}\right)\end{array}$ & $\begin{array}{c}M_{\mathrm{f}} \\
\left(\mathrm{g} \mathrm{m}^{-2} \mathrm{y}^{-1}\right)\end{array}$ & $\begin{array}{c}\text { Mean } B_{\mathrm{f}} \\
\left(\mathrm{g} \mathrm{m}^{-2}\right)\end{array}$ & $\begin{array}{c}\text { Turnover rate } \\
\left(\mathrm{y}^{-1}\right)\end{array}$ \\
\hline Near & $81 \pm 22$ & $12 \pm 33$ & $93 \pm 47$ & $70 \pm 21$ & $1.27 \pm 0.57$ \\
Far & $41 \pm 10$ & $4 \pm 5$ & $46 \pm 10$ & $13 \pm 5$ & $3.26 \pm 1.45$ \\
\hline
\end{tabular}

Table 4. Fitting parameters of Eqs. 6 and 7 ( \pm 1 standard error) with significance ( $p$ value).

\begin{tabular}{|c|c|c|c|c|}
\hline & \multicolumn{2}{|c|}{ Model 1 (Eq. 6) } & \multicolumn{2}{|c|}{ Model 2 (Eq. 7) } \\
\hline & Parameter & $p$ value & Parameter & $p$ value \\
\hline$c\left(\mathrm{~g} \mathrm{Cg} \mathrm{DM}^{-1}\right)$ & $0.57 \pm 0.22$ & 0.012 & $0.58 \pm 0.24$ & 0.020 \\
\hline$d\left(\mathrm{~g} \mathrm{C} \mathrm{g} \mathrm{DM}^{-1} \mathrm{~d}^{-1}\right)$ & $0.0021 \pm 0.00087$ & 0.022 & & \\
\hline$d_{\mathrm{f}}\left(\mathrm{g} \mathrm{Cg} \mathrm{DM}^{-1} \mathrm{~d}^{-1}\right)$ & & & $0.0021 \pm 0.00097$ & 0.040 \\
\hline$d_{\mathrm{c}}\left(\mathrm{g} \mathrm{C} \mathrm{g} \mathrm{DM}^{-1} \mathrm{~d}^{-1}\right)$ & & & $0.0020 \pm 0.0018$ & 0.28 \\
\hline$f\left({ }^{\circ} \mathrm{C}^{-1}\right)$ & $0.054 \pm 0.021$ & 0.016 & $0.054 \pm 0.022$ & 0.018 \\
\hline Adjusted $r^{2}$ & 0.59 & & 0.58 & \\
\hline$p$ value & $<0.001$ & & $<0.001$ & \\
\hline
\end{tabular}

$(p<0.01)$ was significantly lower at Near (Table 3$)$.

\subsection{Partitioning of root respiration}

Model 1 and 2 (Eqs. 6 and 7) were significantly fitted to the data set $(p<0.001)$ with an adjusted $r^{2}$ of 0.59 and 0.58 , respectively (Table 4). In Model $2, d_{\mathrm{f}}$ and $d_{\mathrm{c}}$ were almost the same, probably because fixed values were assigned as $B_{\mathrm{c}}$ to Near and Far, respectively, neglecting the spatial variation of $B_{\mathrm{c}}$. In addition, $d_{\mathrm{c}}$ was not significant $(p=0.28)$. Thus, although the performances of the two models were almost the same, we adopted Model 1 (Eq. 6) to partition $R_{\mathrm{r}}$.

The $Q_{10}$ calculated from the parameter $f$ was 1.7. Annual $R_{\mathrm{r}}$ was partitioned into $R_{\mathrm{g}}$ and $R_{\mathrm{m}}$ using the fitting parameters (Table 5). At Near, $R_{\mathrm{g}}$ of fine roots, $R_{\mathrm{m}}$ of fine roots and $R_{\mathrm{m}}$ of coarse roots accounted for 26, 57 and $17 \%$ of their sum (estimated $R_{\mathrm{r}}$ ), respectively. The bias between $R_{\mathrm{r}}$ from Table 2 and the estimated $R_{\mathrm{r}}$ was zero. Meanwhile, $R_{\mathrm{g}}$, fine root $R_{\mathrm{m}}$ and coarse root $R_{\mathrm{m}}$ accounted for 34, 27 and $39 \%$ of their sum at Far;
Table 5. Annual sums $\left(\mathrm{g} \mathrm{C} \mathrm{m}^{-2} \mathrm{yr}^{-1}\right)$ of root respiration $\left(R_{\mathrm{r}}\right)$ from Table 2, fine root growth respiration $\left(R_{\mathrm{g}}\right)$, fine root maintenance respiration $\left(R_{\mathrm{m} \text { fine }}\right)$, coarse root maintenance respiration $\left(R_{\mathrm{m} \_ \text {coarese }}\right)$ and the sum of $R_{\mathrm{g}}, R_{\mathrm{m} \_ \text {fine }}$ and $R_{\mathrm{m} \_ \text {coarse }}($ Sum $)$ at Near $(n=6)$ and Far $(n=4)$, which corresponds to $R_{\mathrm{r} r}$ Values at Near and Far were spatially averaged with a weight of circumference: 3.14 and $6.28 \mathrm{~m}$ for Near and Far, respectively (weighted average). Means ( \pm 1 standard deviation) were shown. Numbers in parentheses denote percentages against Sum.

\begin{tabular}{cccc}
\hline & Near & Far & $\begin{array}{c}\text { Weighted } \\
\text { average }\end{array}$ \\
\hline$R_{\mathrm{r}}$ & $181 \pm 123$ & $51 \pm 34$ & 94 \\
$R_{\mathrm{g}}$ & $47 \pm 12(26)$ & $24 \pm 3(34)$ & $32(30)$ \\
$R_{\mathrm{m} \_ \text {fine }}$ & $104 \pm 31(57)$ & $19 \pm 4(27)$ & $47(44)$ \\
$R_{\mathrm{m} \_ \text {coarse }}$ & $30(17)$ & $27(39)$ & $28(26)$ \\
Sum & $181 \pm 32(100)$ & $70 \pm 4(100)$ & $107(100)$ \\
\hline
\end{tabular}


the bias was $19 \mathrm{~g} \mathrm{C} \mathrm{m}^{-2} \mathrm{yr}^{-1}(37 \%)$. The larger bias at Far was partly due to a smaller number of replications at $\operatorname{Far}(n=4)$ than at Near $(n=6)$. The $R_{\mathrm{g}}$ and fine root $R_{\mathrm{m}}$ were significantly larger at Near $(p<0.05)$. In addition, the respirations were spatially averaged with a weight of circumference: 3.14 and $6.28 \mathrm{~m}$ for Near and Far, respectively. As a result, $R_{\mathrm{g}}$, fine root $R_{\mathrm{m}}$ and coarse root $R_{\mathrm{m}}$ accounted for 30,44 and $26 \%$ of the total $R_{\mathrm{r}}$ on average in a circumferential area between 0.5 and $1.0 \mathrm{~m}$ in radius.

The $R_{\mathrm{g}}$ varied seasonally in parallel with $P_{\mathrm{f}}$ (Figs. $6 \mathrm{~b}$ and 9), whereas $R_{\mathrm{m}}$ varied mainly according to a seasonal variation in $T_{\mathrm{s}}$ (Figs. 1 and 9). The contribution of $R_{\mathrm{g}}$ to fine $\operatorname{root} R_{\mathrm{r}}\left(=R_{\mathrm{g}} /\left(R_{\mathrm{g}}+\right.\right.$ fine root $\left.R_{\mathrm{m}}\right)$ ) was larger at Far with 0.39 in the cold season and 0.59 on average in the warm season than at Near with 0.10 and 0.35 , respectively (Fig. 9c).

\section{Discussion}

We had measured fine root dynamics and soil $\mathrm{CO}_{2}$ efflux simultaneously within the same collar over a year in adjacent larch-dominated deciduous $(\mathrm{DF})$ and evergreen conifer $(\mathrm{EF})$ forests and quantified annual $R_{\mathrm{g}}$ and $R_{\mathrm{m}}$ of tree fine roots on an annual basis using a multiple regression model (Sun et al., 2020). However, the results would include considerable uncertainty because of relatively complex experimental conditions in the field, which arose from forest maturity and rich understory species. The mature forests were relatively rich in SOM, litter accumulation and roots. Thus, the forests had a large spatial variation in $R_{\mathrm{h}}$ originating from SOM and litter accumulation. The large spatial variation made it difficult to separate $R_{\mathrm{s}}$ into $R_{\mathrm{h}}$ and $R_{\mathrm{r}}$ in each pair of collars, because $R_{\mathrm{h}}$ was not presumed to be identical even in two neighboring collars. Consequently, representative $R_{\mathrm{r}}$ was determined from the averages of $R_{\mathrm{s}}$ and $R_{\mathrm{h}}$ in each forest, resulting in a small number of available data for curve fitting $(n=5)$. In addition, the DF had canopy gaps caused by a windstorm, and consequently was rich in herbaceous plants. Thus, in the mature forests, a good portion of $R_{\mathrm{r}}$ originated from coarse roots and herbaceous roots, not fine roots targeted for the study.

In this study, we conducted a similar field experiment over a year in a larch-dominated young forest developing on the bare ground after removing surface organic soil along with coarse woody debris to obtain robust results by simplifying experimental conditions and improving the model. The study site was poor in SOM and litter accumulation. Soil $\mathrm{C}$ concentration was about $30 \%$ of that in DF and showed a decreasing tendency with a distance from tree stems, which was probably caused by the gradient of litter fall. Thus, we believe that $R_{\mathrm{h}}$ was almost equal in each pair by setting two collars on a concentric fashion from an isolated larch tree, which was supported by the fact that $R_{\mathrm{s}}$ was not significantly different in each pair before trenching (Fig. 2). Coefficients of variance (CV) in annual a) Near

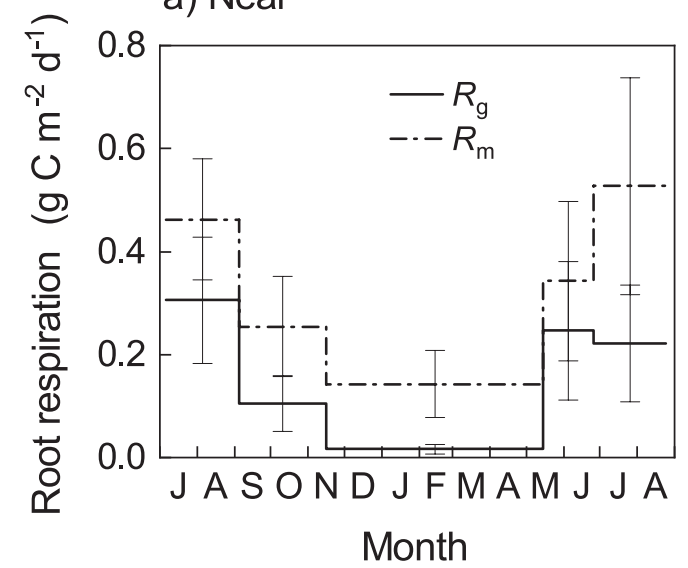

c) Ratio

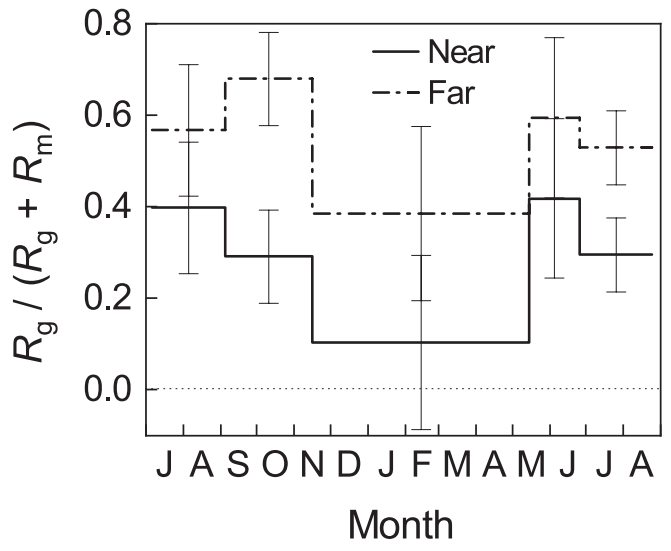

b) Far

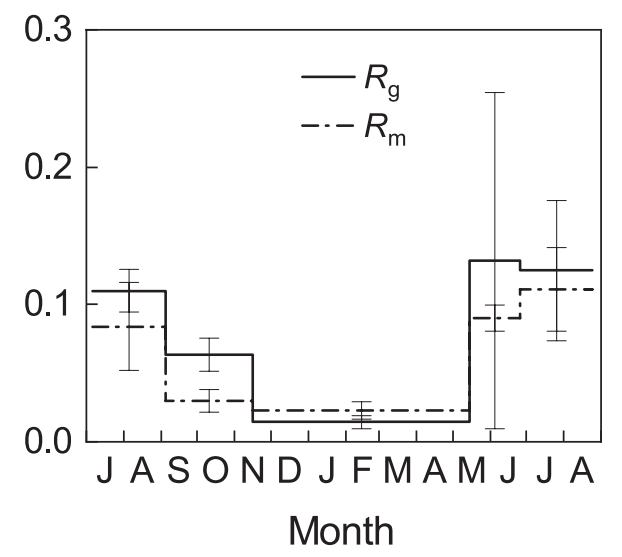

Fig. 9. Temporal variations in fine root growth respiration $\left(R_{\mathrm{g}}\right)$ and maintenance respiration $\left(R_{\mathrm{m} \_ \text {fine }}\right)$ at Near $(\mathrm{a}, n=6)$ and Far $(\mathrm{b}, n=4)$, and the ratio of $R_{\mathrm{g}}$ to the sum of $R_{\mathrm{g}}$ and $R_{\mathrm{m}}(\mathrm{c})$ from July 2017 to August 2018. Means $( \pm 1$ standard deviation) were shown. 
$R_{\mathrm{h}}$ were 24 and $30 \%$, respectively, at Near and Far (Table 2), which were smaller than those of DF (59\%) and EF (39\%). The small $\mathrm{CV}$ also supported the smaller spatial variation in $R_{\mathrm{h}}$. As a result, we were able to calculate $R_{\mathrm{r}}$ in each pair and prepare 50 data sets in total for curve fitting. By separating positions into Near $(0.5 \mathrm{~m})$ and Far $(1.0 \mathrm{~m})$, we were able to use a wide range of data and make significant fitting (Table 4). In addition, understory vegetation was very scarce, and the density of coarse roots $(\geq 2 \mathrm{~mm})$ was low with 55 and $49 \mathrm{~g} \mathrm{~m}^{-2}$, respectively, at Near and Far. The contribution of fine roots to total $R_{\mathrm{r}}$ was large at $83 \%$ at Near (Table 5), whereas it was $45 \%$ and $68 \%$, respectively, at DF and EF. In our previous study (Sun et al., $2020)$, the large $R_{\mathrm{r}}$ of coarse roots and herbaceous roots $(55$ and $32 \%$ ) were treated as a residual without seasonality. In this study, we related coarse root biomass $\left(B_{\mathrm{c}}\right)$ with $T_{\mathrm{s}}$ to estimate $R_{\mathrm{m}}$ (Eq. 6). Since root density was low (Table 3), $\mathrm{CO}_{2}$ emissions through dead root decomposition $\left(R_{\mathrm{DR}}\right)$ was also small at 13 and $8 \mathrm{~g} \mathrm{C} \mathrm{m}^{-2} \mathrm{yr}^{-1}$, respectively, at Near and Far (Table 2), which accounted only $3 \%$ of $R_{\mathrm{s}}$. The small $R_{\mathrm{DR}}$ contributed to decrease uncertainty in estimating $R_{\mathrm{h}}\left(=R_{\mathrm{TC}}-R_{\mathrm{DR}}\right)$ and consequently $R_{\mathrm{r}}$. Moreover, although trenching decreases SWC owing to lack of water uptake by roots (Subke et al., 2006; Sun et al. 2020), no significant SWC decrease was found in trenched collars (Table 1). Thus, the effect of SWC change was negligible.

We improved the reliability of partitioning fine root respiration, as described above. However, there is still uncertainty. Although the temperature response of coarse root $R_{\mathrm{m}}$ was incorporated into the model (Eq. 6) on the assumption that the temperature coefficient $(f)$ was the same as that of fine root $R_{\mathrm{m}}$, inter-collar deference in $B_{\mathrm{c}}$ was not considered using a fixed $B_{\mathrm{c}}$ for all collars at each position. The $R_{\mathrm{g}}$ of coarse roots was also ignored, whereas an annual tree survey using allometric equations suggested an annual coarse root growth of $76 \mathrm{~g} \mathrm{~m}^{-2} \mathrm{yr}^{-1}$. The $B_{\mathrm{c}}$ was calculated to be $276 \mathrm{~g} \mathrm{~m}^{-2}$ in 2017 and $352 \mathrm{~g} \mathrm{~m}^{-2}$ in 2018 for larch trees, accounting for $79 \%$ of all coarse root biomass. In this study, $B_{\mathrm{c}}$ was 55 and $49 \mathrm{~g} \mathrm{~m}^{-2}$, respectively, at Near and Far, which were only $14-20 \%$ of the tree survey result. The reasons for the small $B_{\mathrm{c}}$ are that biomass within $0.5 \mathrm{~m}$ from trees was not included, and that soil samples were taken round isolated larch trees. Wieser and Bahn (2004) continuously measured the coarse root $R_{\mathrm{r}}$ of Pinus cembra and reported that $R_{\mathrm{m}}$ accounted for $73-80 \%$ of the sum of $R_{\mathrm{m}}$ and $R_{\mathrm{g}}$. Using the percentage, the $R_{\mathrm{g}}$ of coarse roots was roughly estimated from coarse root $R_{\mathrm{m}}$ to be 6-8 and 5-7 $\mathrm{g} \mathrm{m}^{-2} \mathrm{yr}^{-1}$, respectively, at Near and Far, which accounted for about $15 \%$ (Near) and 25\% (Far) of fine root $R_{\mathrm{g}}$ (Table 5). In addition, we did not consider the respiration for ion uptake $\left(R_{\mathrm{i}}\right)$. However, $R_{\mathrm{i}}$ is expected to correlate with photosynthesis (Lambers et al., 2008), and fine roots are mainly produced using recent photosynthate (Lynch et al., 2013). Also, the seasonal pattern of $P_{\mathrm{f}}$ (Fig. 6b) is similar to that of GPP of the larch plantation that existed in the study site before a windstorm (Hirano et al., 2003; Hirata et al., 2007). Thus, $R_{\mathrm{i}}$ would be included in $R_{\mathrm{g}}$, because $R_{\mathrm{g}}$ was proportionate to $P_{\mathrm{f}}$.

Since the study site was a young forest with a small amount of soil carbon, litter accumulation and roots, soil $\mathrm{CO}_{2}$ efflux was considerably smaller than those of adjacent forests. For example, annual values of $P_{\mathrm{f}}$, mortality $\left(M_{\mathrm{f}}\right)$ and mean $B_{\mathrm{f}}$ at Near were 22, 26 and $30 \%$ of those in DF, respectively (Table 3 ). As a result, annual $R_{\mathrm{s}}$ and $R_{\mathrm{r}}$ at Near was 39 and $29 \%$ of those in DF (Table 2). In contrast, annual $R_{\mathrm{h}}$ at Near accounted for $74 \%$ of that in DF, even though soil carbon concentration was only $30 \%$ of that in DF. The larger $R_{\mathrm{h}}$ than expected from carbon concentration was probably due to a difference in the decomposability of SOM. Older SOM in DF could have more recalcitrant fractions (Ryan and Law, 2005). The ratio of $R_{\mathrm{r}}$ to $R_{\mathrm{s}}$ was $37 \%$ at Near (Table 2) and $48 \%$ in DF, which is consistent with the fact that the contribution of $R_{\mathrm{r}}$ decreases as $R_{\mathrm{s}}$ increases (Subke et al., 2006). The growth respiration coefficient $\left(g_{\mathrm{R}}\right)$ of $0.57 \mathrm{~g} \mathrm{C} \mathrm{g} \mathrm{DM}^{-1}$ is equivalent to $48 \mathrm{mmol} \mathrm{CO}_{2} \mathrm{~g} \mathrm{DM}^{-1}$ and almost doubles those in DF and EF (Table 4). Meanwhile, the maintenance respiration coefficients $\left(g_{\mathrm{m}}\right)$, which is equivalent to $d \cdot \exp \left(f \cdot T_{\mathrm{s}}\right)$, were 2.6, 4.6 and $7.8 \mathrm{nmol} \mathrm{CO}_{2} \mathrm{~g} \mathrm{DM}^{-1} \mathrm{~s}^{-1}$ at 5,15 and $25^{\circ} \mathrm{C}$, respectively. Although the $g_{\mathrm{m}}$ at $25^{\circ} \mathrm{C}$ was equal to that in DF, $g_{\mathrm{m}}$ was $2-3$ times higher at 5 and $15^{\circ} \mathrm{C}$, because the base coefficient $(d)$ was much higher but the temperature coefficient $(f)$ was lower than those in DF. In comparison with previous studies conducted in the field for Pinus taeda and Liquidambar styaciflua (George et $a l ., 2003$ ) and in a greenhouse for eucalyptus cuttings (M'Bou et $a l ., 2010)$, the $g_{\mathrm{R}}$ and $g_{\mathrm{m}}$ of this study were about ten times higher and slightly lower, respectively. The variation in the coefficients is mainly due to differences in species, environmental conditions and methods (Lambers et al., 2008).

The $Q_{10}$ values calculated from a seasonal variation in soil $\mathrm{CO}_{2}$ efflux was reported to be higher in $R_{\mathrm{r}}$ than in $R_{\mathrm{h}}$ (Boone et al., 1998; Wang et al., 2010), because it is confounded with root phenology like in Figs. 6 and 7. Wang et al. (2010) also reported that the mean $Q_{10}$ values from 13 forest sites were 3.40 and 2.42, respectively, for $R_{\mathrm{r}}$ and $R_{\mathrm{h}}$. In this study, the $Q_{10}$ of $R_{\mathrm{r}}$ was about 2.0 and was equivalent to that of $R_{\mathrm{h}}$. We think that the lower $Q_{10}$ of 2.0 was quite possible, because it was a combined result of the apparent $Q_{10}$ values of $P_{\mathrm{f}}\left(4.48\right.$ and 2.51), $B_{\mathrm{f}}$ (1.08 and 1.49) (Fig. 7) and $R_{\mathrm{m}}$ (1.7) (Eq. 6). However, uncertainty might be large in $Q_{10}$ calculation, because $\mathrm{CO}_{2}$ efflux data at low temperatures were insufficient; $Q_{10}$ is sensitive to data at low temperatures.

Soil $\mathrm{CO}_{2}$ efflux was continuously estimated from the monitoring data of $T_{\mathrm{s}}$ (Fig. 1) using an exponential equation (Eq. 1). Although constant $R_{\mathrm{s}}$ of 0.61 and $0.42 \mathrm{~g} \mathrm{C} \mathrm{m}^{-2} \mathrm{~d}^{-1}$ were shown during the snowy season in Fig. 5 , the $R_{\mathrm{s}}$ might be a little overestimated in comparison with winter $R_{\mathrm{s}}\left(0.5 \mathrm{~g} \mathrm{C} \mathrm{m}^{-2} \mathrm{~d}^{-1}\right)$ measured under snow in an undisturbed deciduous forest about $5 \mathrm{~km}$ apart from the study site (Hirano, 2005). The overestimation was probable caused by uncertainty of the parameters of Eq. 1 (Fig. 3), because data were lacking at low temperatures $\left(<10^{\circ} \mathrm{C}\right)$. In the dormant season, roots respire using NSC accumulated during the previous growing season (Furze et al., 2019; Collalti et al., 2020). Small $P_{\mathrm{f}}$ of about $0.04 \mathrm{~g} \mathrm{~m}^{-2} \mathrm{~d}^{-1}$ was measured both at Near and Far in the cold season from mid-November to mid-May (Fig. 6b). Although some studies reported fine root growth in winter (Radville et al., 2016), the $P_{\mathrm{f}}$ might include spring $P_{\mathrm{f}}$ after snowmelt in early April. The $R_{\mathrm{g}}$ and $R_{\mathrm{m}}$ of fine roots showed obvious seasonal variations (Fig. 9), reflecting the seasonality of $P_{\mathrm{f}}$ and $T_{\mathrm{s}}$, respectively. At Near, $R_{\mathrm{g}}$ was smaller than $R_{\mathrm{m}}$ throughout a year, whereas $R_{\mathrm{g}}$ was 
slightly larger in the warm season at Far (Fig. 9c). The difference between Near and Far was caused by different turnover rate of fine roots $\left(=P_{\mathrm{f}} /\right.$ Mean $\left.B_{\mathrm{f}}\right)$ (Table 3$)$, though the turnover rate at Far had a large $\mathrm{SD}$. The contribution of $R_{\mathrm{g}}$ to $R_{\mathrm{r}}$ increases with increasing turnover rate.

\section{Conclusions}

In comparison with our previous study, we decreased the number of parameters and incorporated the maintenance respiration of coarse roots in the model for partitioning. Moreover, we simplified the experimental conditions in the field and controlled spatial variation in heterotrophic respiration and contamination from roots other than fine roots. The improvement decreased uncertainty in experiments and considerably increased data size available for model parametrization. As a result, we succeeded in significant partitioning of root respiration into growth and maintenance respirations of fine roots. Also, we quantified the seasonal variation of the growth and maintenance respirations. To improve the partitioning further, spatial variation in coarse root density should be considered, and more frequent measurement of fine root dynamics is given priority.

\section{Acknowledgement}

This study was supported by JPSP KAKENHI (17K20037) and the Environment Research and Technology Development Fund (JPMEERF20172005 and JPMEERF20202006) of Environmental Restoration and Conservation Agency of Japan. We thank the Hokkaido Regional Office of the Forestry Agency for allowing us to use the study site, and N. Saigusa, R. Hirata and the staff of CGER for managing the site.

\section{References}

Abramoff RZ, Finzi AC, 2015: Are above- and below-ground phenology in sync? New Phytologist 20, 1054-1061.

Amthor J, 2000: The McCree-de Wit-Penning de Vries-Thornley respiration paradigms: 30 years later. Annals of Botany 86, $1-20$.

Beer C, Reichstein M, Tomelleri E et al., 2010: Terrestrial gross carbon dioxide uptake: global distribution and covariation with climate. Science 329, 834-838.

Bond-Lamberty B, Thomson A, 2010: Temperature-associated increases in the global soil respiration record. Nature 464 , 579-582.

Boone RD, Nadelhoffer KJ, Canary JD et al., 1998: Roots exert a strong influence on the temperature sensitivity of soil respiration. Nature 396, 570-572.

Brunner I, Bakker MR, Björk RG et al., 2013: Fine-root turnover rates of European forests revisited: an analysis of data from sequential coring and ingrowth cores. Plant and Soil 362, 357-372.

Cannell MGR, Thornley JHM, 2000: Modeling the components of plant respiration: some guiding principle. Annals of Botany 85, 45-54.

Chapin FS III, Matson PA, Vitousek PM, 2011: Plant carbon budgets. In Principle of Terrestrial Ecosystem Ecology. Springer, New York, pp. 157-181.

Chen D, Zhang Y, Lin Y et al., 2009: Stand level estimation of root respiration for two subtropical plantations based on in situ measurement of specific root respiration. Forest Ecology and Management 257, 2088-2097.

Collalti A, Tjoelker MG, Hoch G et al., 2020: Plant respiration: Controlled by photosynthesis or biomass? Global Change Biology 26, 1739-1753.

Davidson EA, Richardson AD, Savage KE et al., 2006: A distinct seasonal pattern of the ratio of soil respiration to total ecosystem respiration in a spruce-dominated forest. Global Change Biology 12, 230-239.

Finér L, Ohashi M, Noguchi K et al., 2011: Fine root production and turnover in forest ecosystems in relation to stand and environmental characteristics. Forest Ecology and Management 262, 2008-2023.

Furze ME, Huggett BA, Aubrecht DM et al., 2019: Whole-tree nonstructural carbohydrate storage and seasonal dynamics in five temperate species. New Phytologist 221, 1466-1477.

George K, Norby RJ, Hamilton JG et al., 2003: Fine-root respiration in a loblolly pine and sweetgum forest growing in elevated $\mathrm{CO}_{2}$. New Phytologist 160, 511-522.

Gholz HL, Wedin DA, Smitherman SM et al., 2000: Long-term dynamics of pine and hardwood litter in contrasting environments: towards a global model of decomposition. Global Change Biology 6, 751-765.

Hanson PJ, Edwards NT, Gartedn CT et al., 2000: Separating root and soil microbial contributions to soil respiration: A review of methods and observations. Biogeochemistry 48, 114-146.

Hirano T, 2005: Seasonal and diurnal variations in topsoil and subsoil respiration under snowpack in a temperate deciduous forest. Global Biogeochemical Cycles 19, GB2011, doi:10.1029/2004GB002259.

Hirano T, Hirata R, Fujinuma Y et al., 2003: $\mathrm{CO}_{2}$ and water vapor exchange of a larch forest in northern Japan. Tellus Series B-Chemical and Physical Meteorology 55, 244-257.

Hirano T, Suzuki K, Hirata R, 2017: Energy balance and evapotranspiration changes in a larch forest caused by severe disturbance during an early secondary succession. Agricultural and Forest Meteorology 232, 457-468.

Hirata R, Hirano T, Saigusa N et al., 2007: Seasonal and interannual variations in carbon dioxide exchange of a temperate larch forest. Agricultural and Forest Meteorology 147, 110-124.

Johnson IR, 1990: Plant respiration in relation to growth, maintenance, ion uptake and nitrogen assimilation. Plant, Cell \& Environment 13, 319-328.

Lambers H, Chapin FS III, Pons TL, 2008: The role of respiration in plant carbon balance. In Plant Physiological Ecology Springer, New York, pp. 132-150.

Lynch DJ, Matamala R, Iversen CM et al., 2013: Stored carbon partly fuels fine-root respiration but is not used for production of new fine roots. New Phytologist 199, 420-430.

Makita N, Kosugi Y, Dannoura M et al., 2012: Patterns of root respiration rates and morphological traits in 13 tree species in a tropical forest. Tree Physiology 32, 303-312.

Marsden C, Nouvellon Y, M'Bou AT et al., 2008: Two independent estimations of stand-level root respiration on clonal Eucalyptus stands in Congo: up scaling of direct measurements on roots versus the trenched-plot technique. New Phytologist 177, 676-687.

M'Bou AT, Saint-André L, de Grandcourt A et al., 2010: Growth and maintenance respiration of roots of clonal Eucalyptus cuttings: scaling to stand-level. Plant and Soil 332, 41-53.

McCormack ML, Dickie IA, Eissenstat DM et al., 2015: Redefining fine roots improves understanding of 
below-ground contributions to terrestrial biosphere processes. New Phytologist 207, 505-518.

McCree KJ, 1974: Equation for the rae of dark respiration of white clove and grain sorghum, as functions of dry weight, photosynthetic rate, and tempearture. Crop Science 14: 509-514.

Moyano FE, Atkin OK, Bahn M et al., 2009: Respiration from roots and the mycorrhizosphere. In Soil Carbon Dynamics ed. by Kutsch W, Bahn M, Heinemeyer A, Cambridge University Press, New York, pp. 127-156.

Neumann M, Godbold DL, Hirano Y et al., 2020: Improving models of fine root carbon stocks and fluxes in European forests. Journal of Ecology 108, 496-514.

Penning de Vries FWT, 1974: Substrate utilization and respiration in relation to growth and maintenance in higher plants. Netherlands Journal of Agricultural Science 22, 40-44.

Radville L, McCormack ML, Post E et al., 2016: Root phenology in a changing climate. Journal of Experimental Botany 67, 3617-3628.

Rewald B, Rechenmacher A, Godbold DL, 2014: It's complicated: intraroot system variability of respiration and morphological traits in four deciduous tree species. Plant Physiology 166, 736-745.

Richter DD, Markewitz S, Trumbore SE et al., 1999: Rapid accumulation and turnover of soil carbon in a re-establishing forest. Nature 400, 56-58.

Ryan MG, Law BE, 2005: Interpreting, measuring, and modeling soil respiration. Biogeochemistry 73, 3-27.

Sano T, Hirano T, Liang $\mathrm{N}$ et al., 2010: Carbon dioxide exchange of a larch forest after a typhoon disturbance. Forest Ecology and Management 260, 2214-2223.

Scott-Denton LE, Rosenstiel TN, Monson RK, 2005: Differential controls by climate and substrate over the heterotrophic and rhizospheric components of soil respiration. Global Change Biology 11, 1-12.

Sha L, Teramoto M, Noh NJ et al., 2021: Soil carbon flux research in Asia: A review and future perspectives. Journal of Agricultural Meteorology 77, 24-51.

Silver WL, Miya RK, 2001: Global patterns in root decomposition: comparisons of climate and litter quality effects. Oecologia 129, 407-419.

Subke JA, Inglima I, Cotrufo MF, 2006: Trends and methodological impacts in soil $\mathrm{CO}_{2}$ efflux partitioning: A metaanalytical review. Global Change Biology 12, 921-943.

Sun L, Teramoto M, Liang N et al., 2017: Comparison of litter-bag and chamber methods for measuring $\mathrm{CO}_{2}$ emissions from leaf litter decomposition in a temperate forest. Journal of Agricultural Meteorology 73, 59-67.

Sun L, Hirano T, Yazaki T et al., 2020: Fine root dynamics and partitioning of root respiration into growth and maintenance components in cool temperate deciduous and evergreen forests. Plant and Soil 446, 471-486.

Sun Q, Li B, Zhang T et al., 2017: An improved Biome-BGC model for estimating net primary productivity of alpine meadow on the Qinghai-Tibet Plateau. Ecological Modelling 350, 55-68.

Sweetlove LJ, Williams TC, Cheung CY et al., 2013: Modelling metabolic $\mathrm{CO}_{2}$ evolution- a fresh perspective on respiration. Plant, Cell \& Environment 36, 1631-1640.

Thornley JH, 2011: Plant growth and respiration re-visited: maintenance respiration defined - it is an emergent property of, not a separate process within, the system - and why the respiration : photosynthesis ratio is conservative. Annals of Botany 108, 1365-1380.

Thornley JHM, 1970: Respiration, growth and maintenance in plants. Nature 227, 304-305.

Vogt KA, Vogt DJ, Bloomfield J, 1998: Analysis of some direct and indirect methods for estimating root biomass and production of forests at an ecosystem level. Plant and Soil 200, 71-89.

Wang W, Chen W, Wang S, 2010: Forest soil respiration and its heterotorphic and autotrohic components: Global patterns and responses to temperature and precipitation. Soil Biology \& Biochemistry 42, 1236-1244.

Wieder RK, Lang GE, 1982: A critique of the analytical methods used in examining decomposition data obtained from litter bags. Ecology 63, 1636-1642.

Wieser G, Bahn M, 2004: Seasonal and spatial variation of woody tissue respiration in a Pinus cembra tree at the alpine timberline in the central Austrian Alps. Trees 18, 576-580.

Yuan ZY, Chen HYH, 2010: Fine root biomass, production, turnover rates, and nutrient contents in boreal forest ecosystems in relation to species, climate, fertility, and stand age: Literature review and meta-analyses. Critical Reviews in Plant Sciences 29, 204-221.

Yuan ZY, Chen HYH, 2012: Indirect methods produce higher estimates of fine root production and turnover rates than direct methods. PLoS ONE 7, e48989.

Yuan ZY, Chen HYH, 2013: Simplifying the decision matrix for estimating fine root production by the sequential soil coring approach. Acta Oecologica 48, 54-61. 